AGRO-INDUSTRI

Vol. 3 No.1 ; Juni 2016

\title{
OPTIMASI PENAMBAHAN MINYAK ATSIRI BUNGA KAMBOJA TERHADAP LILIN AROMATERAPI DARI LILIN SARANG LEBAH
}

\author{
${ }^{*}$ DWI SANDRI ${ }^{1}$, FATIMAH $^{1}$, ERFANUR ADLHANII $^{1}$, LISDA ERLINDA $^{1}$ \\ ${ }^{1}$ Jurusan Teknologi Industri Pertanian, Politeknik Negeri Tanah Laut, Jl. A. Yani, Km. 6, Ds. \\ Panggung, kec. Pelaihari, kab Tanah Laut, Kalimantan Selatan
}

Naskah diterima : 14 April 2016 ; Naskah disetujui : 20 Mei 2016

\begin{abstract}
ABSTRAK
Aromaterapi adalah salah satu teknik pengobatan atau perawatan menggunakan aroma harum yang terdapat pada minyak atsiri. Minyak atsiri dapat dipadukan dengan lilin sebagai media relaksasi. Lilin yang digunakan dapat diperoleh dari sarang lebah madu. Sejauh ini di daerah Tanah Laut para petani lebah madu tidak memanfaatkan kembali sarang lebah setelah dipanen. Pemanfaatan sarang lebah dapat ditingkatkan lebih lanjut dengan dibuat menjadi lilin lebah aromaterapi. Tujuan penelitian ini untuk menentukan kondisi optimum penambahan minyak atsiri aroma kamboja serta menganalisis kualitas lilin lebah aromaterapi. Penelitian ini dilakukan dengan optimasi penambahan minyak atsiri bunga kamboja sebanyak 1\%, 2\%, 3\%, 4\%. Berdasarkan pengujian lilin lebah aromaterapi yang terbaik yaitu aromaterapi kamboja dengan penambahan minyak atsiri sebanyak $1 \%$.
\end{abstract}

Kata kunci : aromaterapi, lilin lebah, minyak atsiri, kamboja

\section{PENDAHULUAN}

Indonesia dikenal sebagai salah satu penghasil minyak atsiri terbesar untuk komoditi tertentu. Lebih dari 90\% minyak atsiri Indonesia diekspor, sementara sisanya untuk kebutuhan lokal. Selain itu masih banyak tanaman penghasil minyak atsiri yang belum dikembangkan secara optimal, sehingga peluang untuk berbisnis minyak atsiri di Indonesia masih cukup besar dan sangat potensial untuk dikembangkan. Sebagai salah satu pusat mega biodiversiti, Indonesia menghasilkan 40 jenis dari 80 jenis minyak atsiri yang diperdagangkan di pasar dunia.

Produk turunan minyak atsiri sangat banyak digemari. Penggunaan minyak atsiri dalam berbagai macam produk rumah tangga, seperti untuk desinfektan, penyegar ruangan, pewangi pakaian, dan untuk aromaterapi. Pemanfaatan minyak atsiri menjadi lilin aromaterapi berpotensi besar untuk dijadikan usaha, hal ini terkait dengan tuntutan hidup yang semakin besar yang mendorong setiap orang bekerja keras sehingga menimbulkan rasa lelah dengan berwisata relaksasi lilin aromaterapi dapat memberikan ketenangan. Lilin dapat terbuat dari bahan baku lemak hewan, malam lebah, dari parafin dan stearin. Menurut Lamar, dkk., (1976) manfaat lilin lebah adalah untuk bahan membatik, lilin penerang, industri kosmetik, cold cream, lipstick dan berbagai lotion. Pada industri farmasi, lilin lebah digunakan untuk bahan pembuatan plester atau kain pembalut, obat-obatan luar, campuran bahan-bahan tahan air/water proof, selain itu juga bisa digunakan sebagai campuran tinta, pensil, semir serta sebagai zat pengkilat.

"Korespondensi:

Telp. : 081346248883

Email : dwisandri@yahoo.com 
Budidaya lebah madu di Kabupaten Tanah Laut berpotensi positif untuk di kembangkan di wilayah ini karena di dukung oleh pakan lebah madu yang banyak. Dinas Kehutanan Kabupaten Tanah Laut (2014) menyebutkan untuk lokasi budidaya lebah madu tersebar di beberapa Kecamatan yaitu Takisung, Panyipatan, Batu Ampar, Bajuin, Pelaihari, Jorong, dan Kecamatan Kurau. Hanya saja sarang lebah di Tanah Laut masih sangat kurang pemanfaatannya. Pada pemanenan madu biasanya sarangnya tidak dimanfaatkan lebih lanjut oleh para peternak lebah. Lilin yang berasal dari sarang lebah tersebut hanya dimanfaatkan untuk pembuatan pondasi rumah untuk sarang lebah dan sebagai lilin untuk penerangan. Lilin lebah akan lebih bernilai ekonomis jika digunakan untuk aromaterapi.

Kamboja memiliki aroma yang harum dan khas. Kandungan senyawa- senyawa atsiri yang terdapat dalam kamboja diantaranya geraniol, sitronelol, dan linalool (Farooque dkk., 2012). Senyawa- senyawa atsiri tersebut sangat bermanfaat, antara lain dapat memberi efek relaksasi, mengurangi stress, dan mengusir nyamuk.

Guna untuk mengoptimalkan dan memecahkan permasalahan pemanfaatan sarang lebah yang masih kurang, maka perlu adanya upaya untuk memanfaatkan sarang lebah tersebut dengan memadukan minyak atsiri kamboja menjadi sebuah produk yang bernilai ekonomis yaitu membuat menjadi lilin lebah aromaterapi dengan berbagai perlakuan konsentrasi minyak atsiri aroma kamboja. Parameter uji kualitas lilin lebah aromaterapi yang dilakukan meliputi uji organoleptik, uji waktu bakar dan uji titik leleh.

\section{METODE PENELITIAN}

\section{Alat dan Bahan Penelitian}

Alat yang digunakan antara lain Kompor, Panci, Saringan, Hot plate, neraca/timbangan, Gelas Beaker, Termometer, Batang Pengaduk, Mikro Pipet, Pipa Paralon, Cawan Petri, Pipet tetes, Kulkas dan Gunting. Bahan penelitian ini bahan baku utamanya adalah lilin lebah yang didapatkan dari Kelompok Tani Harapan Makmur kabupaten Tanah Laut, minyak atsiri aroma kamboja diperoleh dari Toko Abdullah Parfum Banjarbaru dan sumbu lilin yang terbuat dari benang.

\section{Ekstraksi Lilin Lebah}

Sarang lebah dipilih yang masih bagus dengan ciri berwarna agak kuning muda, bukan yang sudah berwarna coklat dan berbau busuk. Sarang lebah dipanaskan pada suhu $65^{\circ} \mathrm{C}$ pada wadah yang telah ditambahkan dengan air hingga ada cairan yang meleleh dan mengapung. Kotoran yang masih ada dipisahkan dengan cairan lilin dengan cara disaring. Dinginkan cairan lilin dan ambil lilin lebah yang mengapung dan mengeras. Untuk memurnikan lilin, panaskan lagi dengan suhu $90^{\circ} \mathrm{C}$ dan dinginkan.

\section{Pembuatan Lilin Aromaterapi}

Ditimbang lilin lebah sebanyak 15 gram, dipanaskan lilin dengan suhu $70-85^{\circ} \mathrm{C}$, diturunkan sampai suhu $60-65^{\circ} \mathrm{C}$ kemudian dicampurkan dengan minyak kamboja dengan konsentrasi minyak atsiri $1 \%, 2 \%, 3 \%$, dan $4 \%$ kemudian diaduk hingga merata, setelah itu dituang ke gelas kecil yang telah diletakkan sumbu dan diamkan selama 2 jam, didapatlah lilin aromaterapi.

\section{Uji Titik Leleh}

Menurut Turnip (2003) titik leleh diperoleh dengan pengujian metode pipa kapiler, lelehan lilin dihisap ke dalam pipa kapiler, kemudian disimpan di dalam lemari es pada suhu $4-10^{\circ} \mathrm{C}$ 
selama 16 jam. Pipa kapiler diikatkan pada termometer dan dimasukkan kedalam gelas piala 600 $\mathrm{ml}$ yang berisi air setengah bagian. Gelas piala dipanaskan, pada saat lilin dalam pipa kapiler bergerak pertama kali, angka yang terlihat pada termometer dicatat sebagai titik leleh lilin.

Proses penelitian terhadap titik leleh lilin dengan langkah pertama lilin dibakar lelehan lilin dihisap, kemudian disimpan dalam lemari es selama 16 jam. Ikatkan pipet tetes dengan termometer dan dimasukkan ke dalam gelas beaker $500 \mathrm{ml}$ yang berisi air setengah bagian. Dipanaskan gelas beaker, pada saat lilin dalam pipet bergerak pertama kali, angka yang terlihat pada termometer dicatat sebagai titik leleh lilin.

\section{Uji Organoleptik}

Uji organoleptik dilakukan dengan mengisi score sheet pada dengan 20 Panelis secara uji organoleptik dengan tingkat kesukaan skala lima yaitu, keterangan skala satu sangat tidak suka, skala dua tidak suka, skala tiga biasa, skala empat suka, dan skala lima sangat suka yang meliputi penampakan lilin secara keseluruhan dan kesukaan aroma saat dibakar, kemudian untuk deteksi aroma pertama kali skor penilaian dibagi menjadi 5 kategori yaitu 0-20 detik, 21-40 detik, 41-60 detik, 61-80 detik, 81-101 detik. Disediakan stopwatch sebagai penghitung waktu, lilin di bakar satu persatu, kemudian Panelis mendeteksi waktu pertama kali merasakan aromaterapi dari lilin dan dicatat waktu yang di lihat pada stopwatch.

\section{HASIL DAN PEMBAHASAN}

Pada pembuatan lilin aromaterapi dari 15 gram lilin murni dicetak didapatkan lilin lebah aromaterapi dengan warna krim kekuningan (Gambar 1) memiliki panjang $3-3,5 \mathrm{~cm}$. Pengujian lilin lebah aromaterapi meliputi pengujian titik leleh, uji waktu bakar, dan uji organoleptik meliputi kesukaan terhadap penampakan lilin secara keseluruhan, kesukaan aroma lilin sebelum dibakar, warna dan keadaan nyala api saat dibakar, dan kesukaan aroma saat lilin dibakar. Hasil pengujian titik leleh ditunjukkan pada Tabel 1.

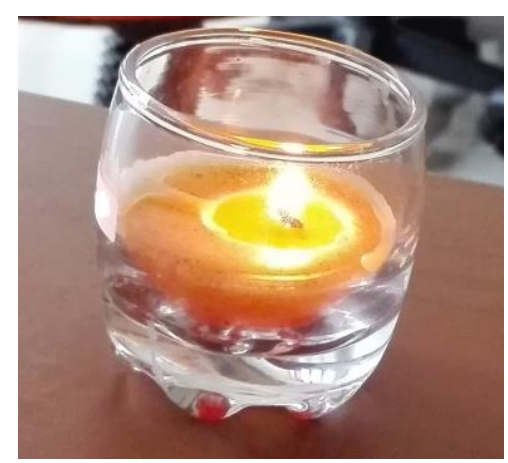

Gambar 1. Lilin aromaterapi lilin lebah

Tabel 1. Uji Titik Leleh Lilin Lebah Aromaterapi

\begin{tabular}{cc}
\hline Perlakuan & Titik Leleh $\left({ }^{\circ} \mathrm{C}\right)$ \\
\hline K1 & 62.7 \\
K2 & 62 \\
K3 & 60.7 \\
K4 & 62 \\
KT & 64 \\
\hline
\end{tabular}


Keterangan:

$\mathrm{K} 1$ : lilin aromaterapi dengan konsentrasi minyak atsiri kamboja $1 \%$

$\mathrm{K} 2$ : lilin aromaterapi dengan konsentrasi minyak atsiri kamboja $2 \%$

$\mathrm{K} 3$ : lilin aromaterapi dengan konsentrasi minyak atsiri kamboja 3\%

$\mathrm{K} 4$ : lilin aromaterapi dengan konsentrasi minyak atsiri kamboja $4 \%$

KT : lilin aromaterapi dengan konsentrasi minyak atsiri kamboja $0 \%$

Titik leleh didefinisikan sebagai suhu fase padat dan cair suatu zat bersama-sama berada dalam keadaan keseimbangan pada tekanan tertentu. Uji titik leleh lilin lebah aromaterapi dilakukan dengan tiga kali ulangan. Berdasarkan SNI 0386 - 1989 - A / SII 0348 - 1980 adalah $50^{\circ} \mathrm{C}$ sampai $58^{\circ} \mathrm{C}$. Hasil uji titik leleh lilin lebah aromaterapi berkisar antara $60-64^{\circ} \mathrm{C}$ dengan titik leleh tertinggi yaitu pada lilin tanpa penambahan aroma kamboja dengan rata-rata titik leleh pada suhu $64^{\circ} \mathrm{C}$. Sedangkan menurut penelitian Turnip (2003) titik leleh lilin aromaterapi dari parafin dan stearin berkisar $53,25^{\circ} \mathrm{C}-55,84^{\circ} \mathrm{C}$. Ini menunjukkan bahwa titik leleh pada parafin dan stearin sudah memenuhi standart SNI, komponen terbesar kedua dari stearin adalah asam oleat yang merupakan asam tak jenuh dan memiliki titik leleh rendah yaitu $14^{\circ} \mathrm{C}$ (Ketaren, 1986). Semakin banyak jumlah asam oleat maka lilin memiliki titik leleh yang rendah, penambahan stearin ke dalam parafin akan menurunkan titik leleh lilin (Oppenheimer, 2001). Hasil untuk titik leleh lilin lebah aromaterapi diatas standar yang telah ditetapkan, hal ini pada lilin lebah menunjukkan jumlah asam oleat yang sedikit pada lilin sehingga titik leleh lilin lebah aromaterapi lebih tinggi.

Waktu bakar adalah selang waktu yang ditunjukkan daya tahan lilin dibakar sampai habis. Lilin diukur sama rata dengan tinggi $2,5 \mathrm{~cm}$ kemudian diletakkan didalam gelas dan dibakar secara bersama-sama dengan dimulai hitungan waktu menggunakan Stopwacth. Uji waktu bakar dilakukan dengan tiga kali ulangan dengan hasil ditunjukkan pada Tabel 2.

Tabel 2. Uji DMRT variasi konsentrasi minyak atsiri kamboja terhadap waktu bakar lilin lebah aromaterapi

\begin{tabular}{cccc}
\hline Perlakuan & $\begin{array}{c}\text { Rerata waktu } \\
\text { bakar (menit) }\end{array}$ & DMRT 5\% & DMRT 1\% \\
\hline K1 & 121 & $\mathrm{c}$ & $\mathrm{bc}$ \\
K2 & 81 & $\mathrm{a}$ & $\mathrm{a}$ \\
K3 & 71 & $\mathrm{a}$ & $\mathrm{a}$ \\
K4 & 106 & $\mathrm{~b}$ & $\mathrm{~b}$ \\
KT & 126 & $\mathrm{c}$ & $\mathrm{c}$ \\
\hline
\end{tabular}

Keterangan: angka-angka yang diikuti huruf yang sama pada kolom yang sama berarti berbeda tidak nyata $(5 \%)$ dan berbeda tidak sangat nyata $(1 \%)$

Data hasil penelitian waktu bakar pada Tabel 2 menunjukkan waktu bakar lilin lebah aromaterapi berada pada kisaran 71 menit sampai 2 jam 6 menit. Waktu bakar yang paling lama adalah lilin lebah tanpa aromaterapi, sedangkan waktu bakar yang paling cepat lilin lebah aromaterapi kamboja dengan penambahan minyak atsiri 3\% yaitu rata-rata 71 menit. Ada beberapa faktor yang mempengaruhi daya tahan lilin diantaranya letak sumbu apabila letak sumbu terpusat maka lelehan lilin merata dan daya tahan lilin baik, komposisi lilin, dan wadah lilin saat pembakaran juga berpengaruh. Penelitian Turnip (2003) menyatakan waktu bakar lilin aromaterapi 
stearin dan parafin berada pada kisaran 5 jam 4 menit sampai 10 jam 47 menit yang terlama lilin dengan komposisi bahan 90 stearin : 10 parafin dan konsentrasi minyak melati $2 \%$. Hal ini menunjukkan semakin banyak stearin yang digunakan, semakin lama panas menembus struktur lilin yang lebih padat dan keras. Perbandingan komposisi bahan pada lilin juga mempengaruhi waktu bakar lilin. Semakin lama waktu bakar menunjukkan semakin lama lilin habis terbakar. Semakin lama waktu bakar yang diperlukan maka kualitas lilin semakin baik.

Berdasarkan uji ANONA pada taraf uji 5\%, konsentrasi minyak atsiri aroma kamboja berpengaruh nyata terhadap waktu bakar lilin aromaterapi. Uji DMRT menunjukkan bahwa lilin aromaterapi dengan konsentrasi minyak atsiri kamboja $1 \%$ berbeda tidak nyata dengan perlakuan kontrol, dimana ini merupakan perlakuan yang terbaik dibandingkan lainnya yang memiliki waktu bakar yang lebih singkat.

Berdasarkan SNI 0386 - 1989 - A / SII 0348 - 1980, keadaan fisik lilin adalah warna yang sama dan merata, tidak retak, tidak cacat dan tidak patah. Uji organoleptik dilakukan untuk mengetahui tingkat kesukaan panelis terhadap lilin aromaterapi, untuk uji organoleptik keseluruhan produk lilin hasil ditunjukkan pada Tabel 3 dan uji organoleptik untuk untuk aroma lilin saat dibakar ditunjukkan pada Tabel 4 berikut,

Tabel 3. Uji DMRT variasi konsentrasi minyak atsiri kamboja terhadap kesukaan panelis pada lilin aromaterapi

\begin{tabular}{cccc}
\hline \multicolumn{3}{c}{ Uji Organoleptik } \\
\hline Lilin & Rerata & DMRT 5\% & DMRT 1\% \\
\hline K1 & 4,1 & B & b \\
K2 & 3,35 & A & a \\
K3 & 3,7 & A & ab \\
K4 & 3,65 & A & ab \\
KT & 3,6 & A & ab \\
\hline
\end{tabular}

Keterangan : angka-angka yang diikuti huruf yang sama pada kolom yang sama berarti berbeda tidak nyata $(5 \%)$ dan berbeda tidak sangat nyata $(1 \%)$

Tabel 4. Uji DMRT pengaruh konsentrasi minyak atsiri kamboja terhadap aroma lilin saat dibakar

\begin{tabular}{cccc}
\hline & \multicolumn{3}{c}{ Uji Organoleptik } \\
\cline { 2 - 4 } Perlakuan & Rerata & $5 \%$ & $1 \%$ \\
\hline K1 & 3,6 & $\mathrm{ab}$ & $\mathrm{ab}$ \\
K2 & 3,3 & $\mathrm{~A}$ & $\mathrm{a}$ \\
K3 & 3,95 & $\mathrm{C}$ & $\mathrm{b}$ \\
K4 & 4,05 & $\mathrm{C}$ & $\mathrm{b}$ \\
KT & 3,05 & $\mathrm{~A}$ & $\mathrm{a}$ \\
\hline
\end{tabular}

Keterangan : angka-angka yang diikuti huruf yang sama pada kolom yang sama berarti berbeda tidak nyata $(5 \%)$ dan berbeda tidak sangat nyata $(1 \%)$

Berdasarkan hasil uji organoleptik data dapat dilihat pada Tabel 3 menunjukkan skala kesukaan satu sampai lima, lilin aromaterapi kamboja pada lilin dengan konsentrasi 1\%, memiliki tingkat kesukaan panelis yang paling tinggi dengan nilai rata-rata 4,1 dibandingkan perlakuan lainnya. Dari data tersebut panelis lebih menyukai penampakan lilin yang ditunjukkan dengan warna yang sama dan merata, tidak retak dan tidak patah. Menurut penelitian Turnip (2003), lilin 
aromaterapi dari parafin dan stearin yang terbaik pada komposisi 50 parafin : 50 stearin dengan konsentrasi minyak atsiri $2 \%$ dibandingkan $4 \%$, hal ini menunjukkan penggunaan jumlah stearin dan parafin yang sama dan konsentrasi yang kecil akan menghasilkan penampakan tekstur lilin yang paling baik. Dalam pembuatan lilin lebah aromaterapi penambahan minyak atsiri yang lebih kecil yaitu $1 \%$ dalam penampakan lilin secara keseluruhan lebih baik dibandingkan penambahan yang lebih besar hal ini berpengaruh terhadap komposisi bahan dalam pembuatan lilin, sehingga untuk analisis ekonomi penambahan minyak atsiri $1 \%$ dapat di rekomendasikan. Berdasarkan uji ANOVA dengan taraf uji 5\% menunjukkan bahwa lilin lebah aromaterapi perlakuan penambahan minyak atsiri kamboja berpengaruh nyata terhadap penampakan lilin secara keseluruhan. Berdasarkan uji DMRT, penambahan minyak atsiri pada lilin lebah aromaterapi dengan penambahan minyak atsiri kamboja $1 \%$ berbeda nyata $5 \%$ dibandingkan dengan perlakuan lainnya.

Uji kesukaan aroma lilin pada saat dibakar dilakukan untuk mengetahui tingkat kesukaan konsumen terhadap aroma yang ditambahkan ke dalam lilin. Setelah sebelumnya dilakukan pengujian aroma secara sensori maka pengujian aroma pada saat lilin dibakar dapat memberikan penilai yang lebih akurat. Minyak atsiri yang ditambahkan pada lilin dengan aroma kamboja dengan konsentrasi yang satu persen sampai dengan empat persen dapat meberikan penilain yang berbeda-beda dari panelis.

Hasil uji organoleptik menunjukkan tingkat kesukaan panelis skor rata-rata berkisar 3,054,05 yang paling tinggi pada lilin dengan konsentrasi minyak atsiri $4 \%$ dan yang paling rendah pada perlakuan tanpa penambahan minyak atsiri. Ini menunjukkan bahwa Panelis menyukai lilin yang memiliki aroma. Berdasarkan uji ANOVA dengan taraf uji 1\%, perlakuan penambahan minyak atsiri pada lilin lebah aromaterapi berpengaruh sangat nyata. Sedangkan uji DMRT $1 \%$ menunjukkan bahwa lilin dengan penambahan minyak atsiri kamboja $1 \%$ berbeda tidak sangat nyata dengan perlakuan konsentrasi minyak atsiri kamboja 3\% dan 4\% dan berbeda sangat nyata dengan perlakuan kontrol.

\section{KESIMPULAN}

Berdasarkan hasil penelitan yang telah dilakukan, maka dapat disimpulkan bahwa kualitas lilin lebah yang terbaik adalah pada aromaterapi kamboja yaitu penambahan minyak atsiri sebanyak $1 \%$. Berdasarkan pengujian titik leleh lilin lebah aromaterapi kamboja penambahan minyak atsiri $1 \%$ rata-rata $62,7^{\circ} \mathrm{C}$, sedangkan waktu bakar selama 121 menit. Berdasarkan uji organoleptik secara organoleptik meliputi penampakan lilin secara keseluruhan dengan rata-rata 4,1 dan aroma saat lilin dibakar nilai rata-rata 3,6.

\section{DAFTAR PUSTAKA}

Bardey, C. 1999. Making candles and potpourri. Black Dog \& Leventhal Publisher, Inc., New York.

Dinas Kehutanan Kabupaten Tanah Laut. 2014. Rencana Pengembangan Sentra Lebah Madu Kabupaten Tanah Laut. Kalimantan Selatan.

Farooque, A.M.D., Mazunder, A., Shambhawee, S., dan Mazumder, R. 2012. Review on Plumeria Acuminata, International Journal on Research in Pharmacy and Chemistry, 2,2. 
Francis, F.J. 1983. Colorimetry of Foods. In M. Pelgrand and E.B. Bagley (ed.) Physical Properties of Foods. AVI Publishing Company, Inc., Westport, Connecticut.

Ketaren, S. 1985. Pengantar Teknologi Minyak Atsiri. Balai Pustaka. Jakarta.

Lamar, P.L.R.M. Marks, and R.J. Amen, 1976. Factor Influencing the Emulsion Stability of Liquid Diets. J. Food Sci. 41:1168-1171.

Oppenheimer, B. 2001. The Candlemaker's Companion Story Books. Massachussets, USA.

Turnip, D.M.S. 2003. Perbedaan Komposisi Bahan Konsentrasi dan Jenis Minyak Atsiri pada Pembuatan Lilin Aromaterapi, Skripsi. Fakultas Teknologi Pertanian Institut Pertanian Bogor. 